\title{
SIMULATION-BASED ANALYSIS OF EARTHEN HERITAGE ARCHITECTURE AS RESPONSIVE REFUGEE SHELTERS (CASE STUDY: DOMES OF NORTHERN SYRIA)
}

\author{
S. Ibrahim ${ }^{1,2, *}$, M. Ali ${ }^{1,2}$, B. Baranyai ${ }^{2,3}$, I.Kistelegdi ${ }^{2,3}$ \\ ${ }^{1}$ Marcel Breuer Doctoral School, Faculty of Engineering and IT, University of Pécs, Hungary - \\ (sonia.eb.arch, modarali.qi)@gmail.com \\ ${ }^{2}$ Szentágothai Research Centre, Pécs, Hungary - (balint.baranyai, kistelegdisoma)@ mik.pte.hu \\ ${ }^{3}$ Department of Building Constructions and Energy Design, Faculty of Engineering and IT, University of Pécs, Pécs, Hungary
}

Commission II - WG II/8

KEYWORDS: Earthen heritage domes, corbelled domes, refugee shelter, energy analysis, numerical thermal simulations, comfort

\begin{abstract}
Syria has been struggling through a continuous conflict for more than nine years so far. This conflict has had a disastrous consequence, for not only Syria urban areas but also its world heritage and historical sites. Moreover, the ongoing conflict resulted in the displacement of over 13 million people that is more than half the population; including more than 6.1 million internally displaced. This long-term encampment is a growing aspect of a growing refugee crisis. The Syrian refugees have to face another crisis in the camps due to a significant shortage of resources and support. One solution was using earthen buildings that have been a traditional architectural style in Syria for 11 thousand years. As a part of the cultural heritage, it depends on community participation and achieves environmental and economic efficiency in addition to preserving memory and identity of the place. This paper discusses the creation of sustainable shelters through the revival of heritage vernacular earthen architecture in northern Syria. A comparative analysis was conducted between the humanitarian agencies shelters (HAS) and different historical vernacular dwellings (HDS) from the same region with an arid steppe climate (hot summer and a short cold winter); they were modelled in numerical thermal simulations framework as a means to assess the shelters' building energy demand and indoor comfort quality. The comparison resulted in the superiority of the heritage dwelling. The paper is concluded with passive approach optimization to the different historical earthen domes with consideration of the historical characteristics and background.
\end{abstract}

\section{INTRODUCTION}

Syria is the scene of the most massive humanitarian and refugee crisis of our time, a continuing cause of suffering for millions, which is garnering a groundswell of support around the world (UNCHR, 2020a). According to the United Nations Refugees Agency UNHCR, the world is witnessing the highest levels of displacement on record (UNHCR, 2019). Over 70 million people around the world were displaced; 25.9 million of them are refugees and 41.3 million (internally displaced people) IDPs. Syria continued to have the biggest forcibly displaced population in the world, with 13 million people at the end of 2018, which is half of the Syrian population (UNHCR, 2020a). More than 6.1 million Syrian people are IDPs; most of them are in northern Syria (UN, 2019). The pace of internal displacement in Syria remains relentless; over 1.8 million people were displaced in 2017 only (UNHCR, 2020). It is not a short-term displacement; some of the IDPs have been living in conditions of internal displacement for eight years at the end of 2019 (Internal Displacement Monitoring Centre, 2019). Furthermore, most of the refugees' situations usually continue for nearly twenty years (UNHCR executive committee of the high commissioner's programme, 2004), that is why a temporary shelter is not one of the paper's objectives but a shelter for long-term displacement. Recently in 2019, over 500.000 displacements took place in northern Syria. Within this number, some people have been displaced multiple times. People have few remaining options to displace to, as most areas that are considered relatively safe are over-crowded (UN OCHA, 2019). Additionally, medical care, food and water take priority over shelter design and performance. Nevertheless, researches proved that insufficient thermal comfort conditions could lead to morbidity and mortality (Lee et al., 2016). Therefore, we assessed different types of refugee shelters from different camps which are provided by humanitarian agencies in northern Syria. Generally, these shelters are ineffective during high summer temperature periods or in winter where temperature can go under freezing point (Albadra et al., 2017) (Albadra et al., 2018). This physical burden in such adverse conditions is added to the psychological stress of refugees. To improve shelter design, it is significant to understand both the current properties of the shelters and their thermal comfort performance and limitations. Accordingly, this paper has investigated for the first time the thermal comfort and energy demand in different geometry design units from refugee camps. The units have been compared with the traditionally inhabited earthen dome houses in northern Syria.

As one of the oldest building materials in the world, earth is an essential vernacular resource. Sun-dried brick (adobe) constitutes one of the most common types of vernacular earth construction technique. It is the most widespread of all contemporary earth technologies and is used throughout large parts of the world. Sundried brick seems well-placed to contribute to the provision of future ecologically sustainable housing in the hot and dry areas of the world (Vellinga et al., 2007). This construction material provides an essential strategy for improving the LCA of the built environment (Christoforou et al., 2016). Consequently, in addition to the humanitarian aim of this paper, the results can stimulate the revival of this architectural heritage, by rehabilitation into shelters for refugees from this region. In Syria, earthen dome architecture is a traditional heritage construction system with thousands of

Corresponding author 
years old. This tradition is the legacy of successive civilisations in the Middle East, which have deeply marked its history and shaped its territory for years. The architectural traces of these civilisations are still alive to testify to a creative and original mix (Bendakir, 2008). Several studies have been done on the historical, archaeological and architectural aspects; these studies constitute the inevitable referent and the essential substance for any strategy of updating, revitalising and enhancing this constructive tradition (Bendakir, 2008). Therefore, when studying the structural behaviour aspect of earthen domes, the dome geometry design was found as the optimal geometrical choice for the adobe material (Rovero and Tonietti, 2012), and in this paper, the energy efficiency aspect was analysed to confirm the earthen domes preponderance. Earth-based materials have been getting a growing interest in recent years because of their "rediscovery" as eco-friendly construction materials with great potential to increase energy efficiency (Parliament, 2018). Despite this interest, there is a lack of reliable scientific research data regarding the indoor comfort and energy efficiency of the historical traditional geometry design in earthen architecture domes in general and in the Middle East in particular. The paper will allow a deeper understanding of the earthen architecture geometry behaviour regarding ecological sustainability and investigates the importance of these ecologically sustainable domes in regions like Syria in steppe arid climate (Vellinga et al., 2007) (Beck et al., 2018). The first step of more comprehensive research to preserve it as an energy-efficient shelter after crises. This paper's hypothesis states that earthen dome house is the best existing shelter geometry in northern Syria considering indoor comfort quality and having the lowest energy demand to reach an acceptable comfort level for refugees. Relevant literature of earthen domes was analysed in the paper and the HDS were compared with the HAS types that are already in use in Northern Syria (in the same climate zone). The hypothesis considers the dome shape as the optimal geometrical choice for earth materials (Rovero and Tonietti, 2012), and the geometry importance as an affordable and available structure, in addition to its attachment to the traditions and social life of refugees in this region. The paper objectives are to analyse current heritage vernacular architecture in northern Syria; Identify the most efficient, low tech and economic shelter; Detect the most efficient and comfortable earthen geometry; Find the best historical, vernacular and passive design parameters depending on simulations and comparative analysis; Optimize the geometries with the historical parameters and implementing a passive approach and conclude with recommendations to passively optimise the existing earthen geometry to responsive heritage, passive refugee shelter design for this region.

\section{METHODOLOGY}

The main body of the research will apply the dynamic thermal simulation method, including the "zonal simulation method" in the framework of IDA ICE 4.8 indoor climate and energy software tool. It is a dynamic whole-year simulation software where the energy balance of a building and its thermal indoor climate are studied ("EQUA. Ida Indoor Climate and Energy," 2020). IDA ICE is one of the popular (Building Energy Simulation) software programs for validation of building energy models used in scientific articles (Ryan and Sanquist, 2012). A case study analysis was undertaken, and the northern part of Syria was chosen to investigate, by considering the most significant number of people in need of shelter, as shown in Figure 1, (UN, 2019). The study area is situated at Latitude $36.18 \mathrm{~N}$ Longitude $37.2 \mathrm{E}$ in an arid steppe climate. The paper analyses the HAS available in northern Syria camps, which are 320 camps until 15 Nov 2019 (Assistance Coordination Unit, 2019).

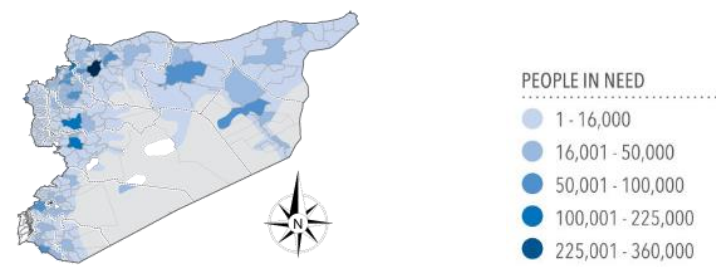

Figure 1. Distribution of people in need of shelter in Syria (UN, 2019).

The steps of the research are shown in Figure 2.

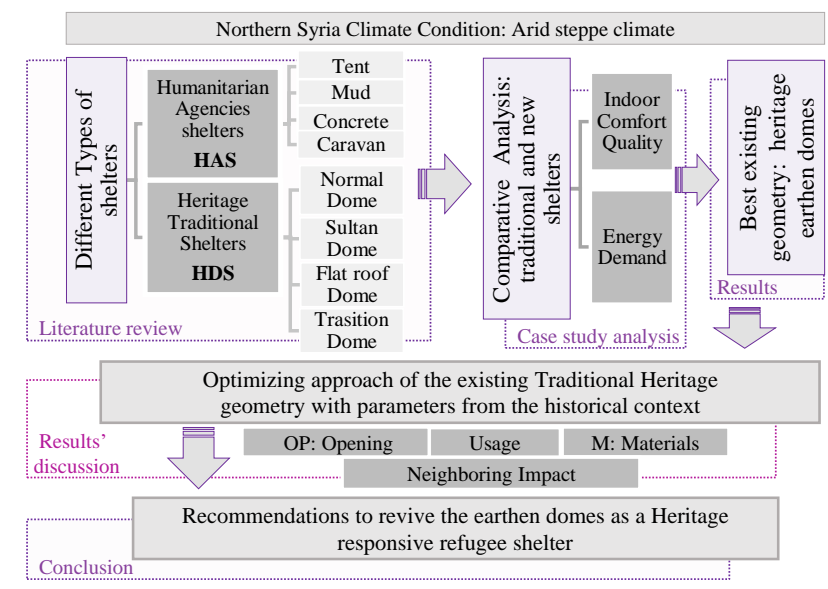

Figure 2. Paper structure diagram for the topic.

\section{INVESTIGATED BUILDING TYPOLOGY}

\subsection{The HAS in northern Syria camps until 15 Nov 2019}

The tents constituted $69 \%$ of total shelters of IDPs within assessed camps, the outer-tent roof and inner tent canvas is made from a polyester-cotton blend (UNHCR Shelter and Settlement Section, 2012). The mud and the concrete rooms constituted 23\%. Caravans constituted 8\%, (Northern Syria CampsDynamo Report, 2019) which are equipped with screed flooring with the walls and roofs made of $40 \mathrm{~mm}$ polyurethane insulated sandwich panel with inner and outer surfaces of $0.35 \mathrm{~mm}$ steel sheet (Albadra et al., 2017).

\subsection{The Earthen architecture of northern villages in Syria}

Sustainable architecture is a type of architecture based on local requirements, building materials, and reflecting local climate and traditions (Niroumand et al., 2013). Earthen domes habitats in northern Syria are traditional architecture shared by east and west The earthen dome villages, which were founded by nomadic people to follow the flock grazing, are located in the north, northeast, and the south of Aleppo's region (Rovero and Tonietti, 2012). The earthen domes are distributed in three large regions from northern Syria (Nariţa et al., 2016) (Abou Sekeh et al., 2009). As shown in Table 1, most of the dome settlements are in Aleppo and Al-Jazira (North Syria). Furthermore, Figure 1 shows that these are also the main regions where people in need of shelters in Syria are in the highest proportions.

\begin{tabular}{|l|c|l|c|}
\hline Geographical Region & $\begin{array}{c}\text { Number of } \\
\text { settlements }\end{array}$ & Geographical Region & $\begin{array}{c}\text { Number of } \\
\text { settlements }\end{array}$ \\
\hline Al-Jazira and Euphrates & 2,175 & Aleppo Hadaba & 1,400 \\
Coast & 1,315 & Al Hass River Basin & 1,310 \\
The Western South & 589 & The Syrian Centre & 100 \\
The High Mountains & 53 & The Syrian Desert & 20 \\
\hline Total & 7,002 & \multicolumn{2}{|c|}{189,989 area } \\
\hline
\end{tabular}


The typological solutions adopted in this architecture is strongly linked to the climate, including the few local resources available for construction. In a context where wood is almost entirely lacking, the system of roofing (dome), which is peculiar for these structures, bears witness to a complex and architecturally valuable building process. The domes constructions made of raw earth that typify the villages in the outskirts of Aleppo represents a typology of settlements showing remarkable effectiveness and environmental sustainability, thanks to its thermal and hygrometric properties in perfect energy and resource-saving criteria (Rovero and Tonietti, 2012). Domes can meet the demand of hygrothermal welfare in Syria's steppe arid climate. The thick earthen walls have a naturally elevated thermal inertia and can regulate the indoor humidity through vapour permeability. The "ogival" or parabolic shape of the dome determines a low incidence of solar irradiation, create self-shadowing, allows the indoor upwards movement of hot air, and permits the runoff of the occasional but torrential (Abou Sekeh et al., 2009). At the same time, the dome shape resists the mechanical stresses of wind pressure and the minor shocks of the earthquakes which afflict the region (Dipasquale and Mecca, 2012). It would be useful to subject these vernacular architecture criteria to the economy and materials of Syrian refugee shelters. In this way, the quality and values inherent of the traditional and human response to the environment might be preserved by applying them in designing responsive shelters and using simulation methods to validate its effective energy performance.

3.2.1 Geometry: Domes in earthen architecture have a wide range of geometries in northern Syria, varying in form aspects and constructive details. The four more common building types were chosen as case studies in the investigation developed.

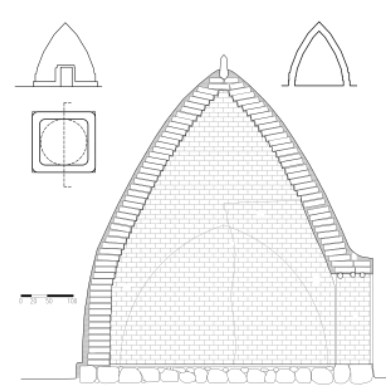

Figure 3. Normal dome.

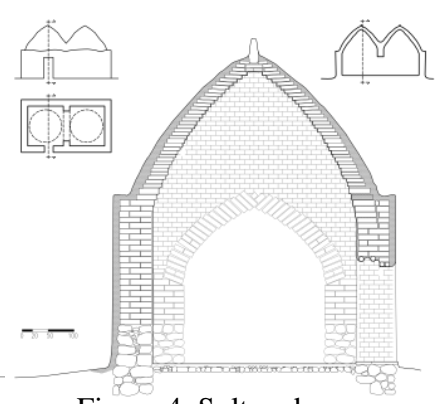

Figure 4. Sultan dome.
The normal dome $(\mathbf{N})$ : (Figure 3 ) it is the oldest style, in which corbelled layers 'false dome', resting on a stone baseboard, which rises only a few centimetres from the terrain surface. This shape encloses the most considerable amount of space with the least surface area (A/V). The sultan dome (S): (Figure 4) the building consists of a box with a paraboloid profile dome cover. The two elements, the box walls and dome, are recognisable from outside. The box has a square base, measuring between 3.00 and $4.50 \mathrm{~m}$. The height ranges from $4 \mathrm{~m}$ to $6 \mathrm{~m}$.

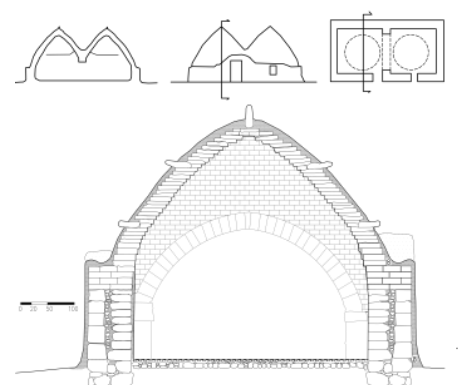

Figure 5. Transition dome.

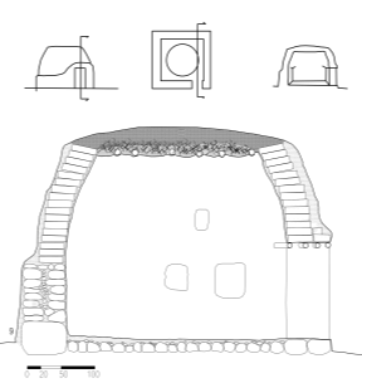

Figure 6. Flat roof dome.
The transition dome (T): (Figure 5) set on low stone basementwall, the building consists of a variable height stone basementwall and a shaped stone profile. Height sizes are variable between $2.5 \mathrm{~m}$ and $4 \mathrm{~m}$. The flat roof dome (F): (Figure 6) it is not a complete dome; the wooden structure roof is flat, covered with earth for protection. This form of construction is common in the villages near the river Euphrates, where the availability of wooden branches made this construction possible (Dipasquale and Mecca, 2012)(Dipasquale et al., 2009b).

3.2.2 The construction of earthen dome: The basement of the dome wall is made of stone and mud. The foundation wall is a stonewall of variable heights, upon which the earthen masonry wall is constructed. The set of building parts realized to achieve the transition from the square base wall to the circular, it is called 'pendentive', the rows of earthen bricks gradually take the shape of the internal perimeter from a square to a circle. The wall is built in horizontal layers, with particular attention to the connection between the walls (Dipasquale et al., 2009b) (Dipasquale et al., 2009a). Openings: Some domes have no openings; the few openings are designed to maintain the internal microclimate: The low ventilation holes permit constant natural ventilation; minimise the sun's flare and the entry of warm air during the day as well as cold air at night. The houses have only a few small doors and windows, to protect them against the external climate (Dipasquale et al., 2009b). Ventilation is ensured by a series of holes, placed in strategic positions depending on climatic conditions and internal function. The holes, mainly east/west oriented, are cut into the wall at varying heights (Dipasquale et al., 2009b). Adobe (earth brick): The size of the bricks varies from village to village, having regular proportions between the three dimensions, a ratio of $1: 2$ between width and length of the brick: the average size is $20 \mathrm{x} 40 \mathrm{x} 10 \mathrm{~cm}$ (Abou Sekeh et al., 2009). Finishes: Mud plaster and limewash finishes are measures to decorate and to preserve the earthen masonry from degradation by weather conditions (Vellinga et al., 2007). (Morot-Sir and Algros, 2009). When available, a lime wash paint is applied for protecting, reflecting sunlight and absorbing less heat during hot seasons (Dipasquale and Mecca, 2012).

\section{MODELLING AND SIMULATION}

\subsection{The model unit}

In Earthen domes, the central space of the house is called a "Gurpha", being the space for housing the family and the reception of guests. It may consist of a single cell (dome), but more often comprises two domes communicating by an arch. (Dipasquale et al., 2009a). "Gurpha" is a unit with multiple functions (living and sleeping) (Dipasquale and Mecca, 2012) (Dello and Mecca, 2009). At first, the authors modelled the "Gurpha" single cell of the house, as it is the primary unit that is repeated when accommodating a larger family. Then, the double unit was considered in the passive approach optimisation. The location, climate profile and wind profile were set identically for all the models. Figure 7 shows the basic geometries which were modelled based on the available documented measurements for the four types of the traditional domes as shown in Figure 3, Figure 4, Figure 5 and Figure 6. Four ventilation holes were simulated and each one measures $(20 \mathrm{~cm} \times 10 \mathrm{~cm})$. Based on the previous description in paragraph 3.2, the different HDS types are varied in area, height, volume, envelope area and envelope area per volume $\mathrm{A} / \mathrm{V}$, as listed in Table 2. The four HAS types were modelled based on unified dimensions, as shown in Table 2. The building materials for each model are based on the documented HAS mentioned in Paragraph 3.1, the thermal properties were identified and set within the software as shown 
in Table 3, (Giada et al., 2019) (Robertson, 1988) ("PU-W-ST polyurethane core sandwich panel," n.d.) (P. INCROPERA et al., 2007) (Brischke and Humar, 2017) (Jhanji et al., 2015). The HAS models are shown also in Figure 7.

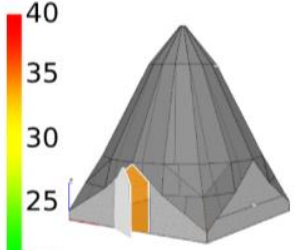

$20 \mathrm{~N}$ : Normal dome

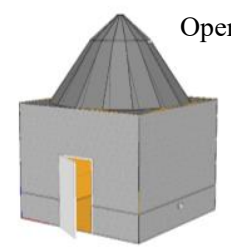

S: Sultan dome

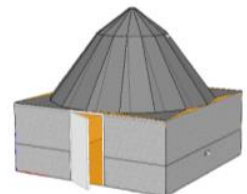

T: Transition dome
Operative temperature, ${ }^{\circ} \mathrm{C}$
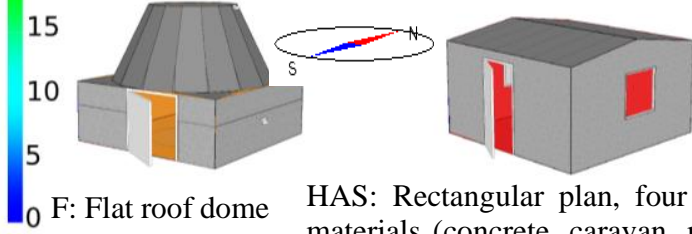

HAS: Rectangular plan, four building materials (concrete, caravan, mud, and

Figure 7. Different simulation models in IDA ICE illustrating the operative temperature during the hottest day of the year (21 Jun) at 16:00.

\begin{tabular}{|l|c|c|c|c|}
\hline Model dimensions & $\mathrm{N}$ & $\mathrm{S}$ & $\mathrm{T}$ & $\mathrm{F}$ \\
\hline Area $\left(\mathrm{m}^{2}\right)$ & 19.36 & 15.21 & 19.36 & 10.56 \\
Height $(\mathrm{m})$ & 5.22 & 5.56 & 5.56 & 2.7 \\
Volume $\left(\mathrm{m}^{3}\right)$ & 51.32 & 59.6 & 48.86 & 20.12 \\
Envelope area $\left(\mathrm{m}^{2}\right)$ & 120.2 & 145.7 & 131.2 & 75 \\
Envelope area per volume & 2.342 & 2.445 & 2.686 & 3.726 \\
$\left(\mathrm{~m}^{2} / \mathrm{m}^{3}\right)$ & & & & \\
Average U-value $\left(\mathrm{W} / \mathrm{m}^{2} \mathrm{~K}\right)$ & 0.793 & 0.793 & 0.8806 & 1.022 \\
\hline Model dimensions & cement & carava & mud & tent \\
\hline Area $\left(\mathrm{m}^{2}\right)$ & 16 & 16 & 16 & 16 \\
Height $(\mathrm{m})$ & 2.5 & 2.5 & 2.5 & 2.5 \\
Volume $\left(\mathrm{m}^{3}\right)$ & 37.6 & 37.6 & 37.6 & 37.6 \\
Envelope area $\left(\mathrm{m}^{2}\right)$ & 79.7 & 75.5 & 91.1 & 72.7 \\
Envelope A/V $\left(\mathrm{m}^{2} / \mathrm{m}^{3}\right)$ & 2.12 & 2.009 & 2.423 & 1.935 \\
Average U-value $\left(\mathrm{W} / \mathrm{m}^{2} \mathrm{~K}\right)$ & 2.595 & 2.516 & 2.182 & 5.206 \\
\hline
\end{tabular}

Table 2. Geometry and thermal pro the investigated models.

\begin{tabular}{|l|c|c|c|}
\hline Material & $\begin{array}{c}\text { Thermal } \\
\text { conductivity } \\
(\kappa) \mathrm{W} /(\mathrm{mK})\end{array}$ & $\begin{array}{c}\text { Density } \\
(\rho) \mathrm{kg} / \mathrm{m} 3\end{array}$ & $\begin{array}{c}\text { Specific } \\
\text { heat }(\varsigma) \\
\mathrm{J} /(\mathrm{kg} \mathrm{K})\end{array}$ \\
\hline Adobe (earthen mud) & 0.42 & 1900 & 847 \\
Limestone & 1.1 & 2700 & 1000 \\
$\begin{array}{l}\text { Zinc } \\
\begin{array}{l}\text { Polyurethane (40 mm } \\
\text { thickness) }\end{array}\end{array}$ & 116 & 7140 & 389 \\
$\begin{array}{l}\text { Poly-Coton canvas } \\
(1.2 \mathrm{~mm} \text { thickness })\end{array}$ & 30 & 252.09 & 1246 \\
\hline
\end{tabular}

Table 3. Thermal properties of materials used in the models.

Identical openings orientation were considered for the units; doors on the southern side, openings on the eastern and the western sides. According to the practice in HDS construction and the HAS shelters, thermal bridges were set as 'poor' and 'very poor', respectively. The number of occupants was set in proportion to the area, namely one occupant per $5 \mathrm{~m}^{2}$. Table 2 also shows the average U-value for each HDS and HAS type, which is related to building materials, envelope geometry, openings and other factors that affect the building envelope's heat transmission. The normal dome shows the best U-value, with the least envelope per area ratio.

\subsection{Thermal comfort}

Full year simulation was run after setting schedules for windows and doors openings. For the domes, the openings were scheduled to be opened the whole year except during the winter. This schedule mimics the typical situation since traditionally residents completely close the openings during winter. The primary investigation was based on the authentic situation; No heating or cooling systems were implemented in the investigated models. The primary aim was to examine the building performance based on its geometry, materials, and authentic design.

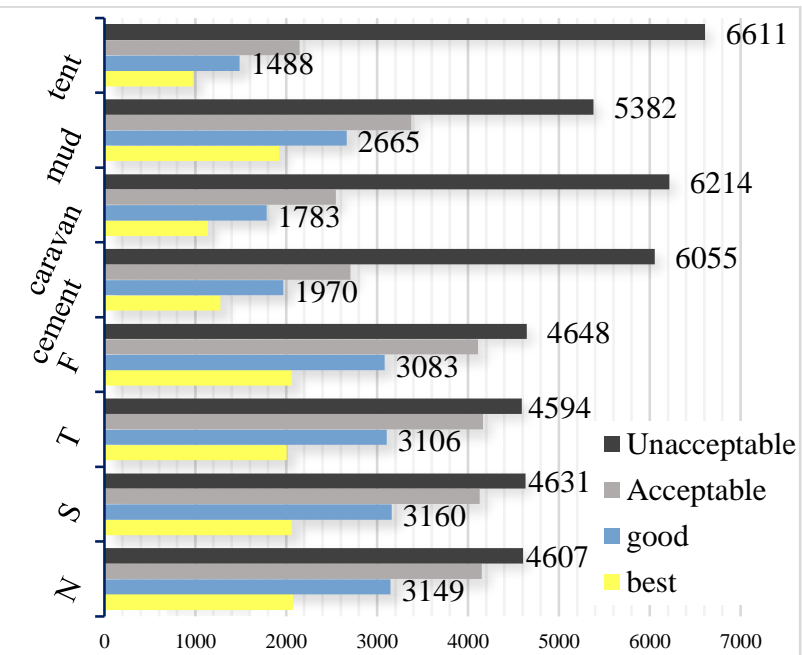

Figure 8. Thermal comfort h/8760, (authentic scenario).

Regarding operative temperature, the transition dome shows the best results and the highest number of 'accepted' hours with only 13 hours better than the normal dome. When looking at the category "best" which represents the better quality of thermal comfort, the normal dome shows the best performance, as shown in Figure 8. (In the simulation the conformance on thermal comfort in zones is based on the rang defined in EN 15251:2007 (IEA (International Energy Agency), 2007)).

The Predicted Mean Vote (PMV) was shown in Figure 9, which illustrate a comparison between the PMV behaviour of the normal dome and the tent, the PMV behaviour is more consistent in the normal dome, even though the tent has 268 more accepted PMV hours with 2226h than the dome with (1958h).

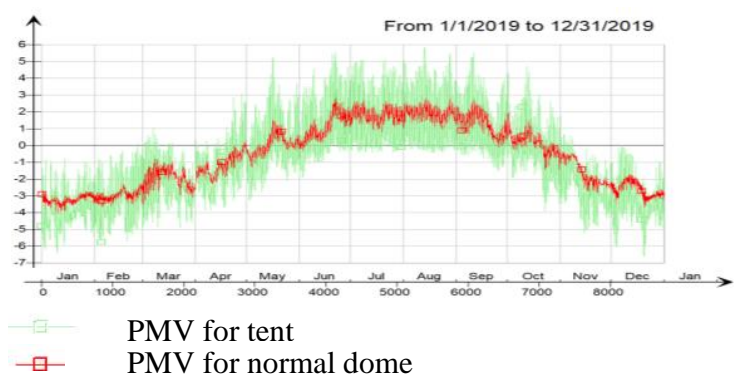

Figure 9. PMV comparison of normal dome and tent (8760h).

Indoor air quality: Indoor air quality was taken based on the yearly number of hours in which the $\mathrm{CO}_{2}$ level is below 1000 ppm, as shown in Figure 10. The heritage domes geometry in 
average provides $13.44 \%$ longer period of acceptable $\mathrm{CO}_{2}$ hours because the domes have the ventilation holes which are open during hot and warm seasons, which provides larger air change rates.

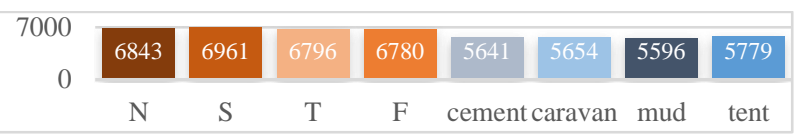

Figure $10 . \mathrm{CO}_{2}$ levels, h/8760.

\subsection{Energy performance analysis in the shelters}

The shelters energy demand was investigated by running load simulations to identify the shelter type that has the least energy demand. Heating and cooling demands were calculated through iteration-based simulations to fulfil the comfort set points during the coldest two months (January and February) and the hottest two months (July and August). The buildings have different areas, which significantly affects the demands. Therefore, the concluded load values were normalised, dividing by the area, for comparison, as shown in Figure 11.

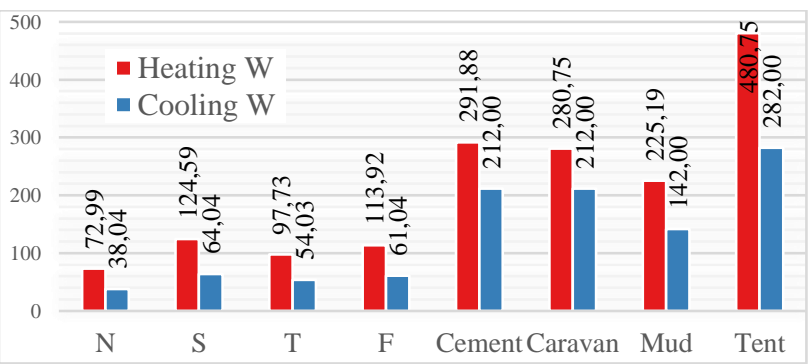

Figure 11. Heating and cooling load calculations for two months $\left(\mathrm{W} / \mathrm{m}^{2}\right)$.

In average, the group of HAS shelters demands $339.5 \%$ more energy for heating and cooling than the group of heritage domes, since the heritage domes envelope structure and its thermal mass limits the heat losses, as shown in Figure 13.

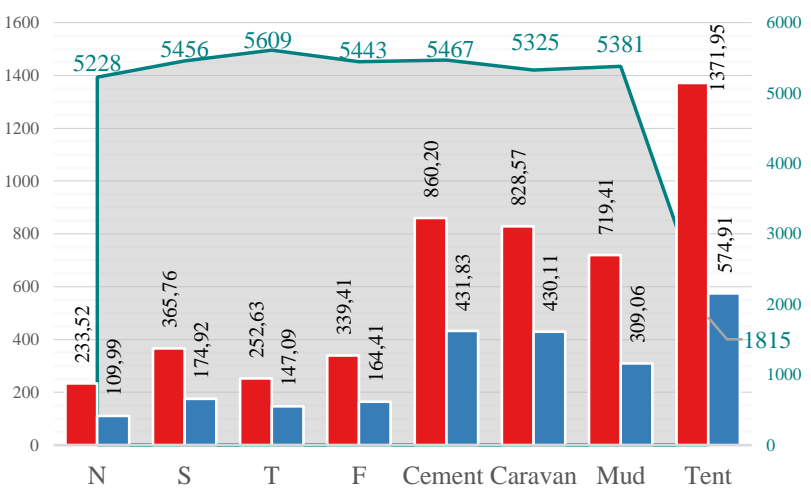

口Acceptable hours (of 8760h) $\Vdash$ Heating $\mathrm{kWh} / \mathrm{m}^{2}$ - Cooling $\mathrm{kWh} / \mathrm{m} 2$

Figure 12. Energy consumption pared with delivered comfort for one year.

For instance, in a comparison between the normal dome which demands the least energy for heating and cooling $\left(111.03 \mathrm{~W} / \mathrm{m}^{2}\right)$ and the tent which demand the highest energy $\left(762.75 \mathrm{~W} / \mathrm{m}^{2}\right)$, we found that total heat loss of the normal dome is $-1500 \mathrm{kWh}$. The tent total heat gain is $4423.6 \mathrm{kWh}$. Based on the calculated demands, ideal heaters and coolers were set and implemented to the units. The energy performance was assessed through running whole-year simulations. The required energy to deliver the comfort level is significantly lower for the heritage domes. The normal dome consumed $343.51 \mathrm{kWh} / \mathrm{m}^{2}$ to deliver $59.68 \%$ acceptable hours of a year as shown in Figure 12. Whereas the tent consumed $1948.86 \mathrm{kWh} / \mathrm{m} 2$ to deliver only $20.72 \%$ of the year acceptable hours of comfort, which reflect its poor performance. The difference in performance was assessed through the simulations, and the consumption is highly influenced by heat balance as shown in Figure 13.

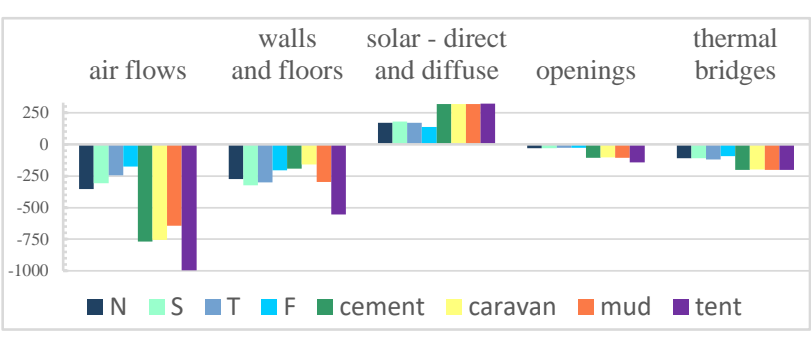

Figure 13. Heat balance for one year, W.

The cooling consumption is affected by heat gains. The heat gains are affected by solar gains, which has approximately double the influence in HAS than in HDS. Heating consumption is affected by heat losses. Heat losses are mainly affected by the airflow, openings and thermal bridges. In comparison, the airflow and openings have approximately triple of the influence in HAS than in HDS; the thermal bridges are approximately double the amount in HAS. Thermal mass affects both cooling and heating, so the influence differs from winter to summer. Due to the type of building materials used, the thermal mass has a positive effect on HDS and a negative effect on HAS. The heat gains are less in summer and the heat losses are less in winter in HDS, which causes less consumption in each season. As an example, a comparison in thermal mass heat balance between the sultan dome and caravan shelter is shown in Figure 14.

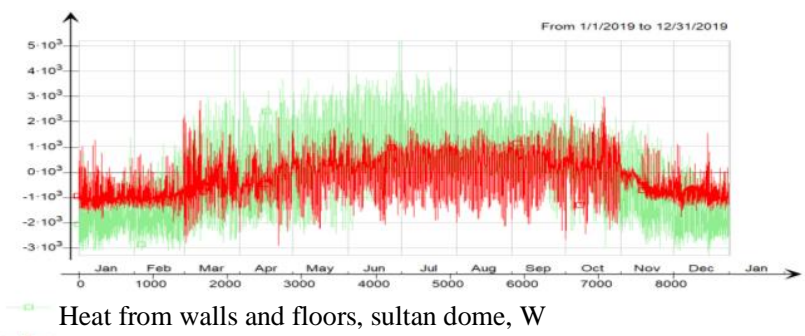

- Heat from walls and floors, caravan, W

Figure 14. Heat from thermal mass, W.

In addition, envelope transmission affects the energy demand therefore Figure 15 illustrates the envelope heat transmission through thermal bridges, walls, roofs and floors before applying the ideal heater and cooler.

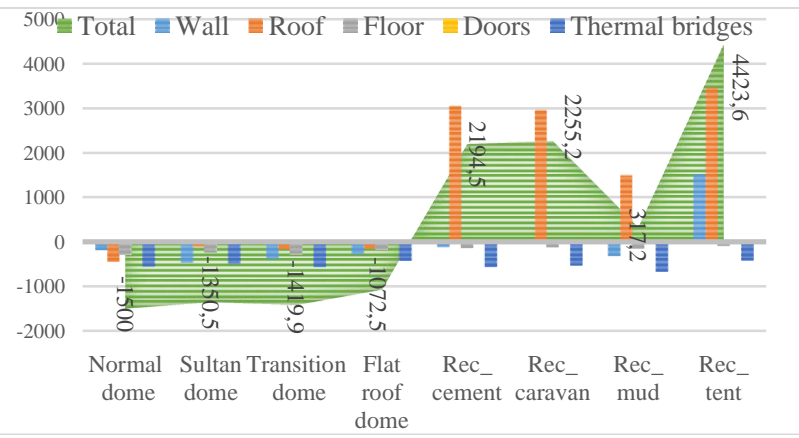

Figure 15. Envelope transmission of one year, kWh. 
The four HDS show significantly better results than the HAS shelters in comfort and energy performance, which proves the research hypothesis that the existing traditional earthen architecture can be reused as refugee shelters and it is better from energy efficiency aspect and, as described before, socially and economically sustainable. Besides, the energy results promise a notable potential in the heritage domes if they are equipped with mechanical heating and cooling systems.

\section{PASSIVE APPROACH FOR OPTIMIZATION AND} ANALYSIS

Since the authentic situation of the refugee shelters is significantly limited in resources, logistics and affordability, the paper's approach is to investigate and optimize the best existing geometry reflecting the realistic situation. Therefore, the passive approach was adopted without any cooling or heating systems.

\subsection{Investigation on the existing heritage domes}

The research will apply several scenarios for passive optimization. These scenarios will be tested and evaluated based on thermal comfort as shown in Figure 8, the $\mathrm{CO}_{2}$ levels as shown in Figure 10 and PMV levels as shown in Table 4, based on acceptable hours. The four HDS types are approximately equal in PMV level. According to ISO 7730 international standard, the seven-point thermal sensation scale recommends the value ' 0 ' (neutral) for PMV. The range between -0.7 and 0.7 (Standardization and Normalisation, 2005) is associated with category III (acceptable) in thermal comfort from Standard EN 15251 (Nicol and Wilson, 2011). After analysing the HDS, different scenarios were created and further assessed and compared in order to get an insight into their comfort criteria. More precisely, the investigation considered PMV, air quality and thermal comfort throughout the year. For analysis, the basic models of the HDS are the pre-assessed simulated models in Figure 7, and six different scenarios are proposed by changing parameters from a historical context. The basic models are the normal dome $(\mathrm{N})$, sultan dome $(\mathrm{S})$, point and Scenario 0 (S0) shown in Table 4.

\begin{tabular}{|l|c|c|c|c|}
\hline Criteria & N & S & T & F \\
\hline PMV & 1958 & 1956 & 1947 & 1902 \\
$\mathrm{CO}_{2}$ Level & 6843 & 6961 & 6780 & 6886 \\
Thermal comfort & 4153 & 4129 & 4166 & 4112 \\
\hline
\end{tabular}

Table 4. S0 (N, S, T, F) showing the basic comfort values for the basic HDS models h/8760.

Each scenario is applied to each basic model when applicable as follows: Scenario S1.N - Model of the dome with increasing wall thickness. An extra adobe bricklayer in this scenario was added only to the normal dome to increase the wall thickness from $47 \mathrm{~cm}$ to $77 \mathrm{~cm}$ which made it similar to the other geometry types. That was because the basic normal dome geometry design has only a single layer of adobe brick. Scenario S2. (N - S -T) - Model of the dome with implementing an additional top opening. The dome model was opened with a top opening instead of the standing stone (tantour) at the highest point of the dome, and the opening was set to $0.07 \mathrm{~m}^{2}$, the $(\mathrm{F})$ dome was exempt because of its roof structure. Scenario S3. (N, S, F, T) - Model of double domes attached with increasing window's area. Two domes were attached in one model, and the total window area was increased from $0.08 \mathrm{~m}^{2}$ to $0.32 \mathrm{~m}^{2}$, which equals 4 times from the basic model as shown in Figure 16. Scenario S4. (N, S, F, T) - Model of the dome with decreasing the window-opening period by 2 months. The windows are closed for 5 months (from November to March) instead of the 3 winter months in the base model, to examine the heat losses differences resulted through airflow in those 2 months. Scenario 5 S5. (N, S, F, T) - Model of the dome with increasing the widow opening area by eight times. The total window area was increased from $0.08 \mathrm{~m}^{2}$ to $0,64 \mathrm{~m}^{2}$, which equals 8 times from the basic model. Scenario 6 S6. (N, S, T, F) - Model of the dome with twice the occupants' number: reflecting the authentic situation and the urgent need for shelters, it is preferred that the unit accommodates as many occupants as possible. Therefore, the number was increased from 1 occupant $/ 5 \mathrm{~m}^{2}$ to 2 occupants $/ 5 \mathrm{~m}^{2}$.

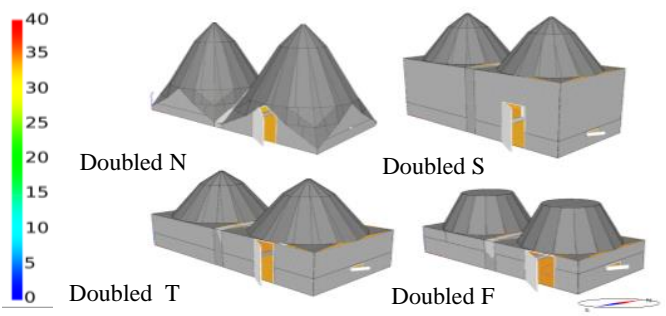

Figure 16. S3. (N, S, F, T) - Doubled domes models illustrating the operative temperature during the hottest day of the year (21 Jun) at 16:004.

\subsection{Results and discussion}

The simulation results are listed in Figure 17. The comparison took the basic model S0 of each type as a reference and was considered as $(0 \%)$. To show the percentage of negative and positive changes influenced by each scenario, different variables were analysed through their effect on the building comfort. In Scenario S1.N when increasing wall thickness in the normal dome, some improvement in indoor comfort quality is present. The extra bricklayer influenced the heat transition through the thermal mass variable. Heat losses were decreased in winter by $39.5 \%$ from $444.5 \mathrm{~W}$ to $268.5 \mathrm{~W}$ and increased in summer by $25.3 \%$ from $309.1 \mathrm{~W}$ to $387.5 \mathrm{~W}$. Thermal comfort accepted hours was increased by $2.5 \%$ from $4153 \mathrm{~h}$ to $4251 \mathrm{~h}$. Accepted PMV hours was increased by $3.3 \%$ from $1958 \mathrm{~h}$ to $2023 \mathrm{~h}$. In Scenario S2. (N - S - T), even though adding a top opening increased the air quality with $0.7 \%$, the comfort is poorer because of the increasing heat losses through airflow. For example, in the case S2.T, the heat losses through airflow were raised $25 \%$ in March and $104.8 \%$ in November. Therefore, the indoor house temperature decreased, adding more unacceptable hours. In Scenario 3 S3. (N-S - T- F), when attaching two domes together with the increased opening area S3. (N-S -T - F), the comfort slightly improved mainly because of fewer heat gains in summer and fewer heat losses in winter from solar due to the domes selfshading. For example, in the case of S3.N, less heat gain by $81 \%$ in summer and fewer heat losses by $27 \%$ in winter. Nevertheless, the air quality was approximately worse on average because the occupants' number was doubled. PMV improvement is $6.35 \%$ on average. Thermal comfort improvement is $4 \%$ on average. In Scenario 4, (S4), when decreasing the window-opening period the comfort had a slight degradation because of the low airquality as the $\mathrm{CO}_{2}$ emissions increased by $12 \%$ because of poor ACR in March and November. For example, the case of S4.N, the heat loss decreased because of changes in airflow ratio during March $62 \%$ more and during January 38\% more. Besides, the heat loss from the window opening significantly changed from $51 \mathrm{~W}$ to $0.8 \mathrm{~W}$ in March. The PMV increased by $6.3 \%$ and the thermal comfort also increased by $2.6 \%$. In Scenario S5. (N - S $\mathrm{T}-\mathrm{F}$ ), when increasing the widow opening area by eight times the comfort decreased. Even though the flat roof dome's PMV increased with $7.7 \%$ as it has the highest $\mathrm{A} / \mathrm{V}$ value so any small change can affect the internal environment. 


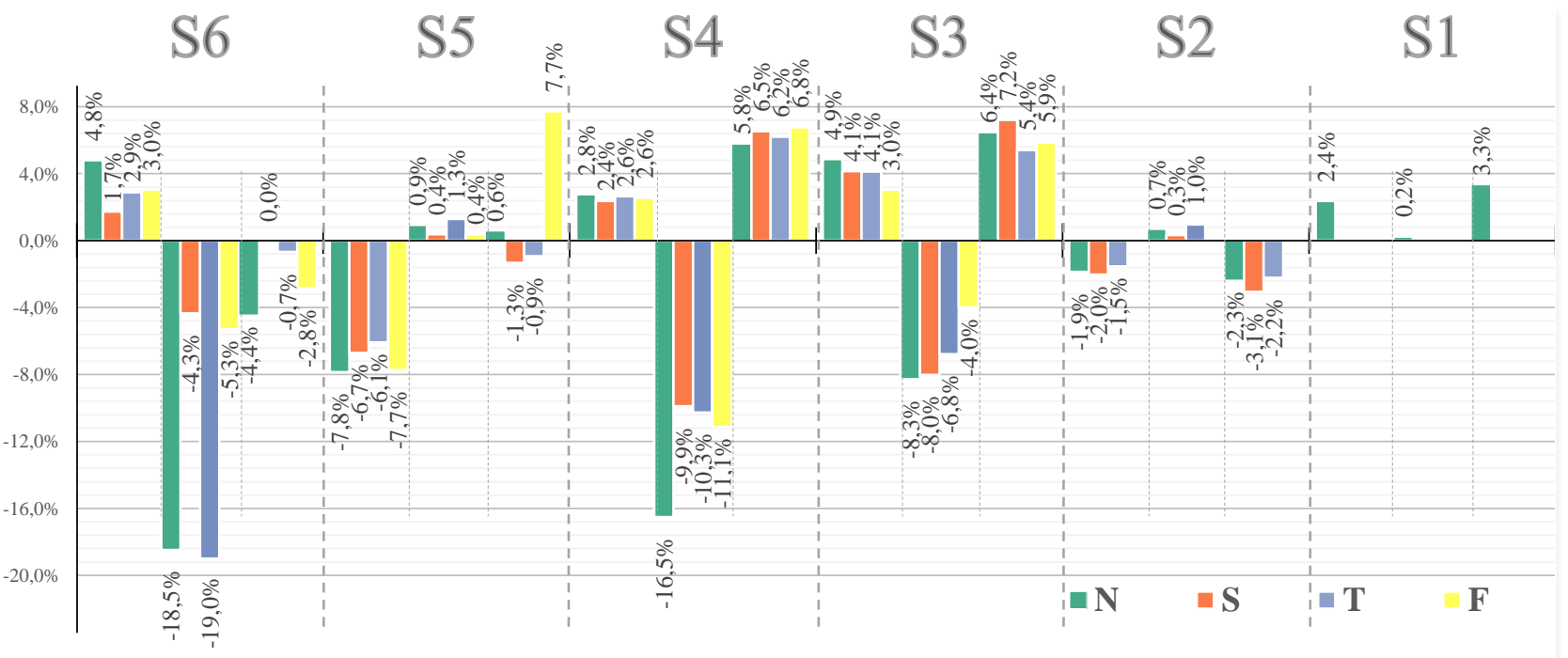

Figure 17. The proportional change measured by the number of hours during one year in terms of thermal comfort, $\mathrm{PMV}$, and $\mathrm{CO}_{2}$ level (shown in that order for every scenario from left to right) when applying the investigated parameters.

In Scenario S6. (N - S - T - F), when increasing the occupants' number twice, the indoor living environment had a slight degradation even though the thermal comfort is $3.1 \%$ better due to the doubled heat emissions from occupants but PMV is approximately $2 \%$ lower, which could distinguish the human wellbeing physical comfort. In S6.S, the form V/A (volume to area) ratio influences the resulted comfort because of the complex correlation between thermal comfort and PMV, so the sultan dome shows $0 \%$ change in PMV with better thermal comfort and the least $\mathrm{CO}_{2}$ concentration.

\section{CONCLUSION}

The long-term encampment is a threatening aspect of a growing refugee crisis, due to the lack of resources; the problem affects the internally displaced people within Syria in a massive way. The paper presented approaches to explore a better refugee shelter that responses to the localized requirements and building materials with less energy demand, reflecting the refugees' poor sources to heat and cool their shelters. The investigation was done in terms of energy demand and indoor comfort quality, by a comparative analysis. In terms of thermal comfort and indoor air quality, it has been confirmed through this paper that the HDS can provide better indoor living conditions compared to HAS shelters. Analyses and results have shown that HDS, regarding PMV, present a stable behaviour compared to HAS. Through this study, it has been demonstrated that HDS's envelope structure and its thermal mass constitutes a determining factor in limiting heat losses in a way that distinguishes the HDS with only $29.4 \%$ of the HAS energy demand for heating and cooling in average. The paper proved the earthen domes superiority over the humanitarian agencies shelters. Furthermore, due to the facts that the dome is the optimal geometrical structure for earth material, which is an essential vernacular recourse, and ecologically sustainable, the humanitarian agencies can consider the earthen domes in their urban crisis response plans in terms of displacement and include it in their shelter design programs. The conducted analysis of dome's authentic geometry and the passive optimisation approach present a reference to the revitalization of local earthen heritage in regions with arid steppe climate, especially that sundried earth is the most widespread of all earth technologies and significantly abandoned heritage. Analysis and optimization scenarios for the basic models ( $\mathrm{S} 0$ ) considered improving indoor comfort quality in an authentic context without mechanical heating or cooling sources. Regarding envelope structure, thickening the dome geometry design by adding an additional layer of adobe or enlarging adobes size contributes to the reduction of heat transitions affected by thermal mass (S1.N). According to that obtained result, it can be concluded that considering this variable during the building process will improve indoor comfort levels in shelters. Regarding openings, when increasing opening area (S2, S5) the comfort degraded due to increasing the heat losses through airflow and when limiting the opening period (S4) the thermal comfort and PMV improved because of the limited heat losses through airflow but all of that with critical $\mathrm{CO}_{2}$ concentration. That can conclude, when rehabilitating the heritage dome it is crucial to maintain the compact geometry design without disregarding the ventilation holes and further research should be conducted with CFD simulations regarding their positions on the dome to enhance indoor air quality. Regarding the usage, due to the complexity of the PMV and thermal comfort, the sultan dome comfort result has shown a better capacity for more refugees (S6.S). Improving indoor comfort levels would recommend multi-domes shelters (S3). Multiple domes, regardless of the type, when attached, have better indoor comfort, as it contributes to the reduction of heat transmission by ambient solar. Nevertheless, more effective openings positioning would be needed to improve $\mathrm{CO}_{2}$ concentration. Additionally, this paper points out the energy efficiency of the dome shelter. As for the energy needed to heat and cool a shelter, there is an increase in energy consumption by $309 \%$ more than the consumption of the domes. Especially for the tent which increased by $435 \%$. That suggests affordability and better environmental impact. Therefore, the energy results promise a notable potential in the heritage domes if they are equipped with mechanical heating and cooling systems.

\section{REFERENCES}

Abou Sekeh, F., Algros, J., Durá, A., Arakadaki, M., Awad, N., Bonora, V. ...Vegas, F., 2009. Earthen Domes and HabitatsVillages of Northern Syria, Earthen Domes and Habitats. 
Albadra, D., Coley, D., Hart, J., 2018. Toward healthy housing for the displaced. J. Archit. 23, 115-136. https://doi.org/10.1080/13602365.2018.1424227

Albadra, D., Vellei, M., Coley, D., Hart, J., 2017. Thermal comfort in desert refugee camps: An interdisciplinary approach. Build. Environ. https://doi.org/10.1016/j.buildenv.2017.08.016

Assistance Coordination Unit, 2019. Northern Syria Camps.

Beck, H.E., Zimmermann, N.E., McVicar, T.R., Vergopolan, N., Berg, A., Wood, E.F., 2018. Present and future köppen-geiger climate classification maps at $1-\mathrm{km}$ resolution. Sci. Data 5. https://doi.org/10.1038/sdata.2018.214

Bendakir, M., 2008. Earthen architectures in Syria: a tradition of eleven millennia [Architectures de terre en Syrie- Une tradition de onze millenaires].

Brischke, C., Humar, M., 2017. Performance of the bio-based materials, in: Performance of Bio-Based Building Materials. Elsevier Inc., pp. 249-333. https://doi.org/10.1016/B978-0-08100982-6.00005-7

Christoforou, E., Kylili, A., Fokaides, P.A., Ioannou, I., 2016. Cradle to site Life Cycle Assessment (LCA) of adobe bricks. J. Clean. Prod. 112, 443-452. https://doi.org/10.1016/j.jclepro.2015.09.016

Dello, M., Mecca, S., 2009. Glossary of earthen architectural terms in Syria. Del.

Dipasquale, L., Mecca, S., 2012. Earthen domes in northern Syria: Problems and criteria for the conservation. Rammed Earth Conserv. 649-654.

Dipasquale, L., Mileto, C., Vegas, F., 2009a. The architectural morphology of corbelled dome houses, in: Earthen Domes et Habitats. Villages of Northern Syria. pp. 267-285.

Dipasquale, L., Onnis, S., Paglini, M., 2009b. Building culture of corbelled dome architecture, in: Earthen Domes et Habitats. Villages of Northern Syria. pp. 323-350.

EQUA. Ida Indoor Climate and Energy [WWW Document], 2020. . EQUA. URL https://www.equa.se/en/ (accessed 1.24.20).

Giada, G., Caponetto, R., Nocera, F., 2019. Hygrothermal Properties of Raw Earth Materials: A Literature Review. Sustainability 11, 5342. https://doi.org/10.3390/su11195342

Internal Displacement Monitoring Centre, 2019. Global Report on Internal Displacement 2019, IDMC. Geneva.

Jhanji, Y., Gupta, D., Kothari, V.K., 2015. Thermo-physiological properties of polyester-cotton plated fabrics in relation to fibre linear density and yarn type. Fash. Text. 2. https://doi.org/10.1186/s40691-015-0041-x

Lee, M., Shi, L., Zanobetti, A., Schwartz, J.D., 2016. Study on the association between ambient temperature and mortality using spatially resolved exposure data. Environ. Res. 151, 610-617. https://doi.org/10.1016/j.envres.2016.08.029

Morot-Sir, P., Algros, J., 2009. Recommendations for technical conservation. Earthen domes et habitats 457-467.
Nariţa, A.-M., Gurza, V., Opriţa, R., Keller, A., Apostol, I., Moşoarcă, M., Bocan, C., 2016. New vulnerabilities of historic urban centers and archaeological sites: Extreme loads. Pollack Period. 11, 15-26. https://doi.org/10.1556/606.2016.11.3.3

Nicol, J.F., Wilson, M., 2011. A critique of European Standard EN 15251: Strengths, weaknesses and lessons for future standards. Build. Res. Inf. 39, 183-193. https://doi.org/10.1080/09613218.2011.556824

Niroumand, H., Zain, M.F.M., Jamil, M., 2013. Assessing of Critical Parametrs on Earth Architecture and Earth Buildings as a Vernacular and Sustainable Architecture in Various Countries. Procedia - Soc. Behav. Sci. 89, 248-260. https://doi.org/10.1016/j.sbspro.2013.08.843

P. INCROPERA, F., P. DEWITT, D., L. BERGMAN, T., S. LAVINE, A., 2007. Fundamentals of Heat and Mass Transfer. John Wiley \& Sons, Inc.

Parliament, E., 2018. Investigating the Thermal Properties of Earth-Based Materials: The Case of Adobes. 10th Int. Symp. Conserv. Monum. Mediterr. Basin. https://doi.org/10.1007/9783-319-78093-1

Robertson, E.C., 1988. THERMAL PROPERTIES OF ROCKS [WWW Document].

Rovero, L., Tonietti, U., 2012. Structural behaviour of earthen corbelled domes in the Aleppo's region. Mater. Struct. Constr. 45, 171-184. https://doi.org/10.1617/s11527-011-9758-1

Ryan, E.M., Sanquist, T.F., 2012. Validation of building energy modeling tools under idealized and realistic conditions. Energy Build. 47, 375-382. https://doi.org/10.1016/j.enbuild.2011.12.020

Standardization, F.O.R., Normalisation, D.E., 2005. International Standard Iso.

\section{UN, 2019. 2019 Humanitarian Needs Overview.}

UN OCHA, 2019. Syrian Arab Republic Recent Developments in Northwestern Syria Situation Report No. 11 - as of 6 September 2019 1-9.

UNCHR, 2020. emergencies [WWW Document]. Syria Emerg. URL https://bit.ly/313B9SW (accessed 1.21.20).

UNHCR, 2020a. Refugee Facts [WWW Document]. Statistics (Ber). URL https://bit.ly/37Px5Y8 (accessed 1.1.20).

UNHCR, 2020b. Internally Displaced People [WWW Document]. Syria. URL https://bit.ly/3ej6jtm (accessed 1.1.20). UNHCR, 2019. Forcibly Displaced People Worldwide [WWW Document]. Fig. a Glance. URL https://bit.ly/3fBTxGM (accessed 1.22.20).

UNHCR executive committee of the high commissioner's programme, 2004. PROTRACTED REFUGEE SITUATIONS.

UNHCR Shelter and Settlement Section, 2012. Shelter Design Catalogue, Shelter Medicine for Veterinarians and Staff. https://doi.org/10.1002/9781119421511.ch3

Vellinga, M., Oliver, P., Bridge, A., 2007. Atlas of vernacular architecture of the world. 